\title{
MIDIATIVISMO DE MULHERES NEGRAS NO SUL DA BAHIA
}

\author{
AUTOR: JESSICA DOS SANTOS DE ASSIS \\ CO-AUTOR/ORIENTADOR: CELIA REGINA DA SILVA
}

Resumo: O estudo se concentra na discussão sobre a apropriação das mídias e o seu uso político como aporte para o combate às violências de gênero e a busca pelo exercício da cidadania de gênero de mulheres negras (pretas e pardas). A presença e a participação feminina na esfera pública midiática são consideradas fundamentais, por favorecerem a equidade de gênero e impulsionarem o processo de desenvolvimento econômico, social e político das sociedades democráticas. Trata-se de espaço aberto que visa impulsionar mulheres no uso de sua criatividade, aprendendo e ensinando técnicas e experiências com a mídia, arte e tecnologia. As mídias sociais ampliaram as possibilidades de comunicação e aproximaram ciência da sociedade. Desse modo, a busca pelo diálogo e a interação com a comunidade tornam-se fundamentais para a divulgação da produção acadêmica e científica e a comunicação junto ao público interno e externo, tendo em vista a capacidade apresentada pelas mídias sociais na divulgação de conhecimento científico. Como aporte teórico utilizou-se as teorias das mídias sociais, dos estudos culturais e do feminismo negro. A metodologia de trabalho, centrada em rodas de conversa (presenciais/ remotas), mostrou-se adequada, tendo em vista ser instrumento metodológico que acelera a interatividade e a participação coletiva. Concluiu-se que, ao mesmo tempo que as mulheres negras sofrem ataques racistas nas redes sociais, aumentou a presença delas como protagonistas de programas, de salas, de livros, de eventos no Youtube, no Instagram, no Facebook, no Watts App. Na universidade inúmeras iniciativas contribuem inclusão social e digital de mulheres negras e indígenas, com destaque para modelos de conhecimentos, alternativos e insurgentes, produzidos por pesquisadoras e militantes do feminismo negro que estão colocando em evidência as combinações das opressões de gênero, raça e classe e outros tipos de discriminação que permeiam o cotidiano de mulheres negras e indígenas. O que tem permitido o aumento de estudos sobre a temática e, mais especificamente, a compreensão sobre a construção de contra narrativas e contra discursos e a formação de sujeitos políticos.

Palavras-chave: Mídia sociais, gênero, feminismo negro e indígena. 